J. Clin. Chem. Clin. Biochem.

Vol. 24, 1986, pp. 155-159

(C) 1986 Walter de Gruyter \& Co. Berlin - New York

\title{
Experience with an Homogeneous Immunoassay for Paracetamol (Acetaminophen)
}

\author{
By R. S. Campbell and C. P. Price \\ Department of Clinical Biochemistry, Addenbrooke's Hospital, Hills Road, Cambridge, U.K.
}

(Received August 30/November 28, 1985)

Summary: The performance of an homogeneous enzyme immunoassay (EMIT ${ }^{\circledR}$ ) for paracetamol (acetaminophen) as configured for the $a c a^{\circledR}$ series of discretionary analysers (Du Pont de Nemours) was evaluated. The method as initially formulated by the manufacturers gave unacceptable. performance which was improved upon, by reagent reformulation and improved kit manufacture procedures, by the manufacturer. The method was fast, precise and free from interference from a range of metabolites, drugs and endogenous physiological compounds. There was good correlation between this method and an enzymatic method for paracetamol (acetaminophen).

\section{Erfahrungen mit einem homogenen Immunassay für Paracetamol (Acetaminophen)}

Zusammenfassung: Ein homogener Enzymimmunassay (EMIT ${ }^{\circledR}$ ) für Paracetamol (Acetaminophen), ausgelegt für die aca ${ }^{\circledR}$-Serie diskreter Analysatoren (DuPont de Nemours), wurde kritisch geprüft. Die ursprünglich vom Hersteller zusammengestellte Methode ergab ein unannehmbares Prüfergebnis. Sie wurde deshalb durch eine neue Zusammenstellung der Reagenzien und verbesserte Testbesteck-Fabrikationsverfahren durch den Hersteller verbessert. Die Methode ist schnell, genau und frei von Interferenzen durch eine Reihe von Stoffwechselprodukten, Arzneimitteln und endogenen physiologischen Verbindungen. Es wurde eine gute Korrelation zwischen dieser Methode und einer enzymatischen Methode für Paracetamol (Acetaminophen) festgestellt.

\section{Introduction}

The quantitation of paracetamol (acetaminophen) in blood is an important investigation in the diagnosis and management of patients suspected of taking an overdose of the drug (1). Accurate quantitation is important in samples taken no earlier than four hours after ingestion since absorption is incomplete before four hours and available antidotes are effective if treatment is commenced within ten hours of ingestion (2). Consequently, an assay that is both rapid and specific is required for routine use.

Amongst the many methods available for the measurement of paracetamol there are several which do not offer the required specificity (3). This specificity is offered by both gas-liquid and high performance liquid chromatographic techniques $(4,5)$. However, these are not techniques which can be held in readiness for immediate use on a twenty four hour basis. More recently method specificity has been achieved with the use of enzymes (6) and antibodies (7).

We report an evaluation of a homogeneous enzyme immunoassay technique for the measurement of paracetamol. The method uses the principle of enzymemultiplied immunoassay (EMIT ${ }^{\circledR}$ ) with a glucose-6phosphate dehydrogenase (EC 1.1.1.49) label (7) and has been configured for use on the aca ${ }^{\circledR}$ series of discretionary analysers manufactured by Du Pont. 


\section{Materials and Methods}

\section{Instrumentation}

The immunoassays were performed on the Du Pont aca ${ }^{\circledR}$ SX discretionary analyser (E. I. Du Pont de Nemours, Wilmington, U.S.A.). The instrument was set up and maintained, and quality control procedures followed, exactly in accordance with the manufacturers instructions.

\section{Reagents}

The reagents conformed to the well established EMIT® (Syva, Palo Alto. U.S. A.) principle as configured for the $a c a^{\circledR}$ analyser systems (8). All of the operational parameters are fixed and all the test packs configured, by the manufacturer, to predetermined performance specifications within the constraints imposed by the operational parameters and system design.

A calibration curve was prepared by assaying six calibrators in quintuplicate and the linearisation parameters of the curve stored in the instruments computer. The manufacturers claim that, once calibrated, further recalibration is unnecessary for 12 weeks for a given pack lot. The reagent test packs for this evaluation were provided in two lots. Data will be presented to show that unacceptable performance of the method noted with the initial pack lot provided was improved by changes made, by the manufacturer, in the formulation of the reagents, in particular the precision of filling of the reagent bubbles in the test packs and the choice of antibody and drug-enzyme conjugate.

\section{Enzyme mediated assay}

The assay is based on the use of the bacterial enzyme aryl acyl amidohydrolase (EC 3.5.1.13) which degrades paracetamol to 4-aminophenol and acetate (6). The 4-aminophenol is detected with 0 -cresol and ammoniacal copper(II) sulphate. The method protocol is as described by Hammond et al. (9) which involves the addition of $50 \mu \mathrm{l}$ of serum or plasma to $1 \mathrm{ml}$ of enzyme reagent and, after incubation at room temperature for two minutes, $1 \mathrm{ml}$ each of $o$-cresol and ammoniacal copper(II) sulphate reagents. After a further incubation for two minutes the absorbance is read at $615 \mathrm{~nm}$.

\section{Procedures and Results}

\section{Precision}

Seven serum pools were prepared with varying paracetamol concentrations. Three pools were prepared from paracetamolfree human serum spiked with the parent drug. Two pools were prepared from EMIT ${ }^{\circledR}$ calibrator solutions. Two further pools were prepared from assayed quality control materials (Ortho TDM control levels II and III, Ortho Diagnostic Systems Inc., Raritan, New Jersey, U.S.A.). Aliquots of each pool were stored at $-20^{\circ} \mathrm{C}$ until assayed. The within batch precision was performed by assaying each pool twenty times in a continuous analytical run. The between day precision was assessed by assaying each pool on twenty working days.

The data for both pack lots are shown in table 1.

\section{Stability of calibration}

After the initial calibration, verification of this calibration was carried out at weekly intervals for the duration of the study. This verification procedure was carried out for both lots of test
packs provided.

The data are shown in figure 1.
Tab. 1. Within and between batch precision for the paracetamol assay.

\begin{tabular}{|c|c|c|c|c|c|}
\hline Material & $\begin{array}{l}\text { Pack } \\
\text { lot }\end{array}$ & $\begin{array}{l}\text { Mean } \\
\text { concen- } \\
\text { tration } \\
(\mathrm{mmol} / \mathrm{l})\end{array}$ & S.D. & $\begin{array}{l}\text { C.V. } \\
(\%)\end{array}$ & $\mathbf{n}$ \\
\hline \multicolumn{6}{|l|}{ Within batch } \\
\hline Serum pool & $\begin{array}{l}1 \\
2\end{array}$ & $\begin{array}{r}.0 .305 \\
0.379\end{array}$ & $\begin{array}{l}0.0113 \\
0.0164\end{array}$ & $\begin{array}{l}3.7 \\
4.3\end{array}$ & $\begin{array}{l}20 \\
20\end{array}$ \\
\hline Serum pool & $\begin{array}{l}1 \\
2\end{array}$ & $\begin{array}{l}0.658 \\
0.736\end{array}$ & $\begin{array}{l}0.0248 \\
0.0184\end{array}$ & $\begin{array}{l}4.5 \\
2.5\end{array}$ & $\begin{array}{l}20 \\
20\end{array}$ \\
\hline Serum pool & $\begin{array}{l}1 \\
2\end{array}$ & $\begin{array}{l}0.881 \\
1.042\end{array}$ & $\begin{array}{l}0.0548 \\
0.0259\end{array}$ & $\begin{array}{l}6.2 \\
2.5\end{array}$ & $\begin{array}{l}20 \\
20\end{array}$ \\
\hline QA material & $\begin{array}{l}1 \\
2\end{array}$ & $\begin{array}{l}0.316 \\
0.320\end{array}$ & $\begin{array}{l}0.0140 \\
0.0084\end{array}$ & $\begin{array}{l}2.1 \\
2.6\end{array}$ & $\begin{array}{l}20 \\
20\end{array}$ \\
\hline QA material & $\begin{array}{l}1 \\
2\end{array}$ & $\begin{array}{l}0.872 \\
0.946\end{array}$ & $\begin{array}{l}0.0697 \\
0.0286\end{array}$ & $\begin{array}{l}8.0 \\
3.0\end{array}$ & $\begin{array}{l}20 \\
20\end{array}$ \\
\hline Calibrator & $\begin{array}{l}1 \\
2\end{array}$ & $\begin{array}{l}0.069 \\
0.064\end{array}$ & $\begin{array}{l}0.0041 \\
0.0033\end{array}$ & $\begin{array}{l}5.9 \\
5.2\end{array}$ & $\begin{array}{l}20 \\
20\end{array}$ \\
\hline Calibrator & $\begin{array}{l}1 \\
2\end{array}$ & $\begin{array}{l}0.335 \\
0.321\end{array}$ & $\begin{array}{l}0.0145 \\
0.0099\end{array}$ & $\begin{array}{l}4.3 \\
3.1\end{array}$ & $\begin{array}{l}20 \\
20\end{array}$ \\
\hline Calibrator & $\begin{array}{l}1 \\
2\end{array}$ & $\begin{array}{l}1.297 \\
1.200\end{array}$ & $\begin{array}{l}0.1111 \\
0.0291\end{array}$ & $\begin{array}{l}8.9 \\
2.4\end{array}$ & $\begin{array}{l}20 \\
20\end{array}$ \\
\hline \multicolumn{6}{|l|}{ Between batch } \\
\hline Serum pool & $\begin{array}{l}1 \\
2\end{array}$ & $\begin{array}{l}0.305 \\
0.381\end{array}$ & $\begin{array}{l}0.0175 \\
0.0118\end{array}$ & $\begin{array}{l}5.7 \\
3.1\end{array}$ & $\begin{array}{l}20 \\
20\end{array}$ \\
\hline Serum pool & $\begin{array}{l}1 \\
2\end{array}$ & $\begin{array}{l}0.632 \\
0.735\end{array}$ & $\begin{array}{l}0.0387 \\
0.0209\end{array}$ & $\begin{array}{l}6.1 \\
2.8\end{array}$ & $\begin{array}{l}20 \\
20\end{array}$ \\
\hline Serum pool & $\begin{array}{l}1 \\
2\end{array}$ & $\begin{array}{l}0.938 \\
1.036\end{array}$ & $\begin{array}{l}0.0890 \\
0.0339\end{array}$ & $\begin{array}{l}9.5 \\
3.3\end{array}$ & $\begin{array}{l}20 \\
20\end{array}$ \\
\hline QA material & $\begin{array}{l}1 \\
2\end{array}$ & $\begin{array}{l}0.310 \\
0.324\end{array}$ & $\begin{array}{l}0.0138 \\
0.0087\end{array}$ & $\begin{array}{l}6.0 \\
2.7\end{array}$ & $\begin{array}{l}20 \\
20\end{array}$ \\
\hline QA material & $\begin{array}{l}1 \\
2\end{array}$ & $\begin{array}{l}0.852 \\
0.933\end{array}$ & $\begin{array}{r}0.0514 \\
0.0297\end{array}$ & $\begin{array}{l}7.8 \\
3.2\end{array}$ & $\begin{array}{l}20 \\
20\end{array}$ \\
\hline Calibrator & $\begin{array}{l}1 \\
2\end{array}$ & $\begin{array}{l}0.0702 \\
0.0669\end{array}$ & $\begin{array}{l}0.0047 \\
0.0037\end{array}$ & $\begin{array}{l}6.7 \\
5.5\end{array}$ & $\begin{array}{l}20 \\
20\end{array}$ \\
\hline Calibrator & $\begin{array}{l}1 \\
2\end{array}$ & $\begin{array}{l}0.331 \\
0.333\end{array}$ & $\begin{array}{l}0.023 \\
0.0078\end{array}$ & $\begin{array}{l}7.0 \\
2.3\end{array}$ & $\begin{array}{l}20 \\
20\end{array}$ \\
\hline Calibrator & $\begin{array}{l}1 \\
2\end{array}$ & $\begin{array}{l}1.367 \\
1.315\end{array}$ & $\begin{array}{l}0.1447 \\
0.0345\end{array}$ & $\begin{array}{l}10.6 \\
2.6\end{array}$ & $\begin{array}{l}20 \\
20\end{array}$ \\
\hline
\end{tabular}

\section{Dilution Curve}

A serum sample known to contain approximately $1.3 \mathrm{mmol} / \mathrm{l}$ paracetamol was diluted in varying proportions with a paracetamol-free serum sample. Similarly the top calibrator was diluted with the zero calibrator in the same proportions as above. The resultant dilutions of the serum pools and calibrators were assayed in duplicate.

The data are shown in figure 2. Linear regression analysis of the data gave (observed) $=0.937 \times(\mathrm{ex}-$ pected) -0.011 with a correlation coefficient of 0.996 for the serum pools, and (observed) $=0.976 \times(\mathrm{ex}-$ pected) +0.016 with a correlation coefficient of 0.998 for the calibrators. 


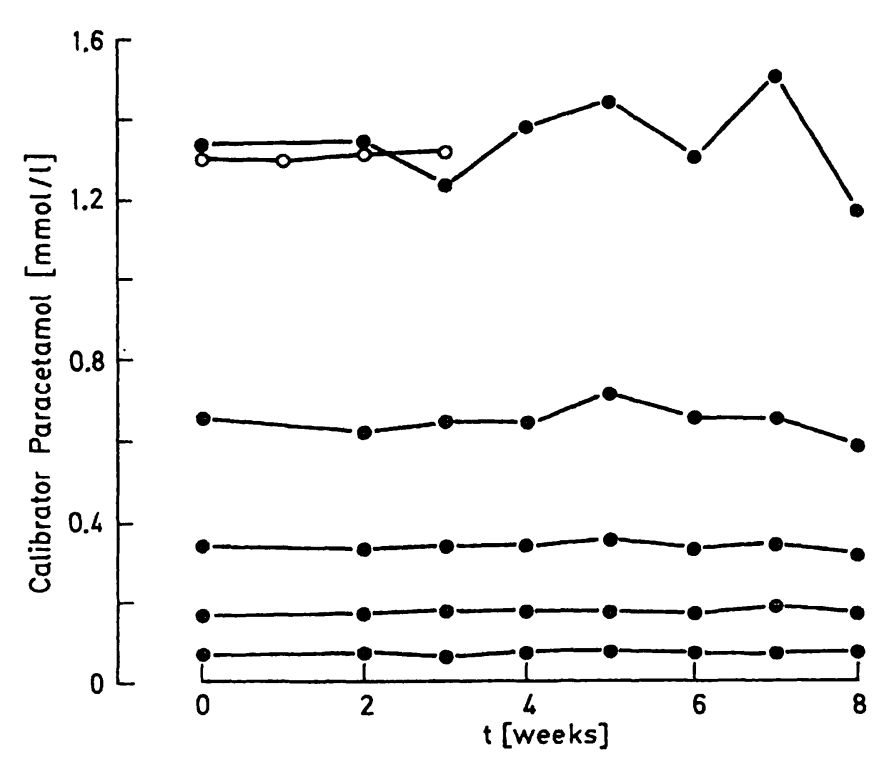

Fig. 1. Analysis of calibrators over a period of 8 weeks to show the stability of calibration for pack lot $1(0)$ and pack lot 2 (0).

\section{Recovery}

Duplicate determinations of the paracetamol concentration were made on ten drug-free serum samples spiked in the proportion $9: 1$ with aqueous paracetamol solutions of 3.0 and 10.0 $\mathrm{mmol} / \mathrm{l}$.

The recovery of paracetamol was found to be within the range $96.7-102.0 \%$ at $0.3 \mathrm{mmol} / 1$ and $90.3-101.4 \%$ at $1.0 \mathrm{mmol} / \mathrm{l}$, with mean values of 98.7 and $96.2 \%$ respectively.

\section{Method Comparison}

Using the first lot of test packs a total of 133 patient samples known to contain paracetamol, within the stated assay range $(0.06-1.32 \mathrm{mmol} / \mathrm{l})$, were assayed by the immuno- and enzymatic procedures. A further 25 samples were collected and assayed using the second lot of test packs and the enzymatic procedure.

The data are shown in figure 3.

\section{Interferences}

\section{Paracetamol metabolites}

Aqueous stock solutions of the paracetamol conjugates, the cysteine, glucuronide, mercapturate and sulphate were diluted with a serum pool containing $0.3 \mathrm{mmol} / \mathrm{l}$ paracetamol. The metabolites were diluted to three concentrations with the serum pool and the paracetamol concentration determined in duplicate. Deionised water replaced the metabolite solutions in the controls.

No interference was observed for any of the metabolites up to the concentration stated, namely cysteine (200 $\mathrm{mg} / \mathrm{l})$, glucuronide (2000 $\mathrm{mg} / \mathrm{l})$, mercapturate (2000 $\mathrm{mg} / \mathrm{l})$ and sulphate $(2000 \mathrm{mg} / \mathrm{l})$.

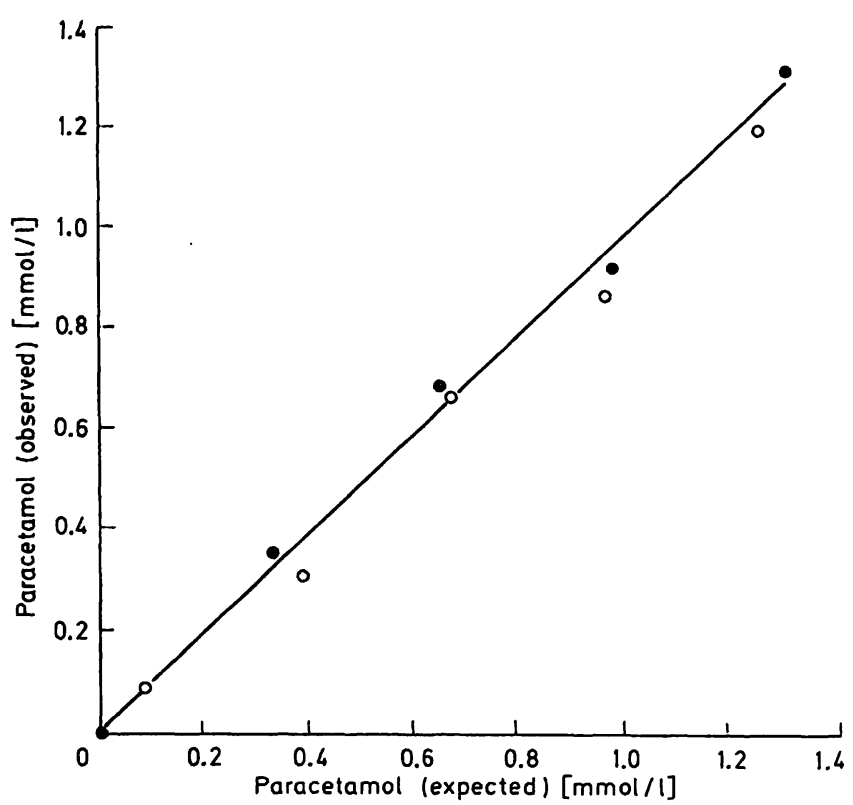

Fig. 2. Dilution curves for the EMIT ${ }^{\circledR}$ paracetamol with a patient's sample $(0)$ and a calibrator $(0)$ being diluted with the zero calibrator.

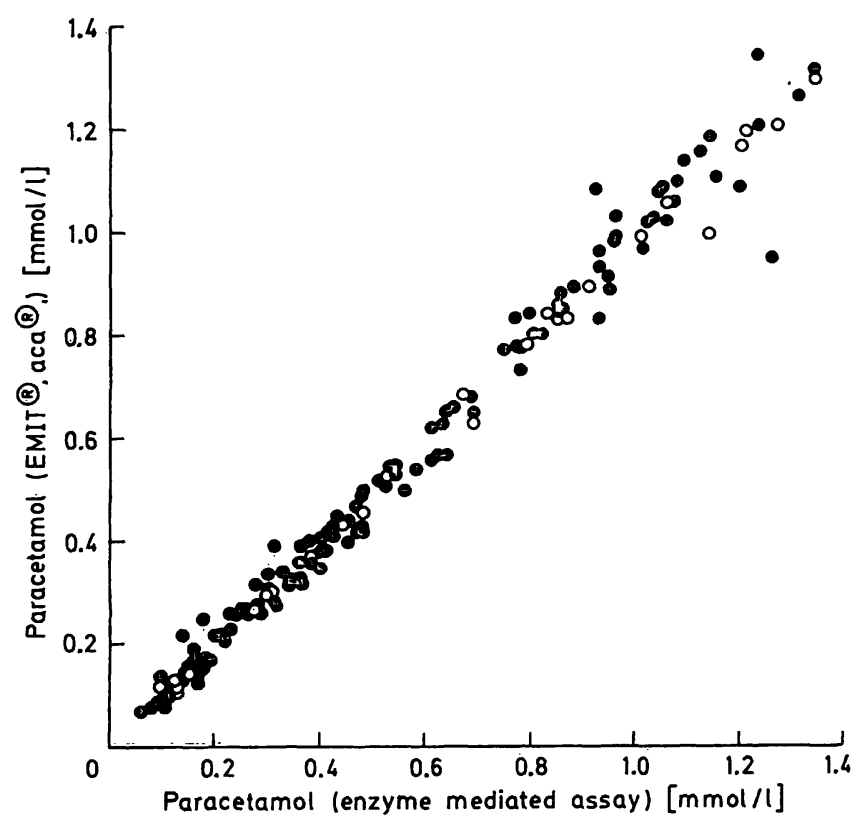

Fig. 3. Comparison of paracetamol results for the Du Pont $a c a^{\circledR}$ and enzymatic methods. Regression parameters, according to the Deming procedure, are $y=0.997 x$ $-0.003, r=0.991, n=133$. Results shown in open circles used pack lot 2 and were excluded from the regression analysis.

\section{Paracetamol overdose antidotes}

The use of thiol-containing compounds in the treatment of patients who have ingested excessive amounts of paracetamol is now well accepted (10). The possible interference of several of the commonly used 
antidotes was tested using the same protocol as employed for the metabolites. No interference was observed for any of the antidotes up to the concentration stated, namely $\mathrm{N}$-acetyl cysteine $(2000 \mathrm{mg} / \mathrm{l})$, cysteamine $(2000 \mathrm{mg} / \mathrm{l})$, cysteine $(2000 \mathrm{mg} / \mathrm{l})$ and methionine $(2000 \mathrm{mg} / \mathrm{l})$.

\section{Common drugs}

The protocol described for the paracetamol metabolites was used for twenty five common drugs and compounds structurally related to paracetamol. Each drug was dissolved in an appropriate solvent to give a stock solution and the relevant solvent was used to dilute the serum pool in the controls. The potential interferent was tested at three concentrations.

No interference was observed with any of the drugs tested up to the concentration stated in table 2 .

\section{Haemolysis, icterus and lipaemia}

Serum pools with elevated haemoglobin, bilirubin and triglyceride concentrations 'were shown to be drug free as were two normal serum pools. Each of the pools was spiked to paracetamol concentrations of approximately 0.3 and $1.0 \mathrm{mmol} / 1$ by the addition of stock aqueous paracetamol solutions of 3.0 and $10.0 \mathrm{mmol} / \mathrm{l}$. The haemolysed, icteric and lipaemic spiked pools were diluted with the spiked normal serum pools in varying proportions and the paracetamol concentrations in each dilution determined in duplicate.

The data are shown in figure 4.

Tab. 2. Drugs tested for interference in the paracetamol method. No interference was noted, and each drug was tested at three concentrations up to the concentrations indicated in brackets ( $\mathrm{mg} / \mathrm{l}$ in all cases).

\begin{tabular}{ll}
\hline Drug tested & $c(\mathrm{mg} / \mathrm{l})$ \\
\hline Acetanilide & 2000 \\
Amitriptyline & 2000 \\
Acetylsalicylate & 4000 \\
Amylobarbitone & 2000 \\
Amphetamine & 1000 \\
Caffeine & 2000 \\
Carbamazepine & 2000 \\
Codeine & 2000 \\
Diazepam & 200 \\
Imipramine & 2000 \\
Lidocaine & 2000 \\
Methadone & 2000 \\
Methaqualone & 2000 \\
N-Acetylprocainamide & 2000 \\
Phenacetin & 2000 \\
Phenytoin & 2000 \\
Phenobarbitone & 2000 \\
Procainamide & 2000 \\
Phenylephrine & 2000 \\
Propoxyphene & 2000 \\
Quinidine & 2000 \\
Salicylic Acid & 4000 \\
Secobarbital & 2000 \\
Theophylline & 2000 \\
Valproate & 2000 \\
& \\
\hline
\end{tabular}

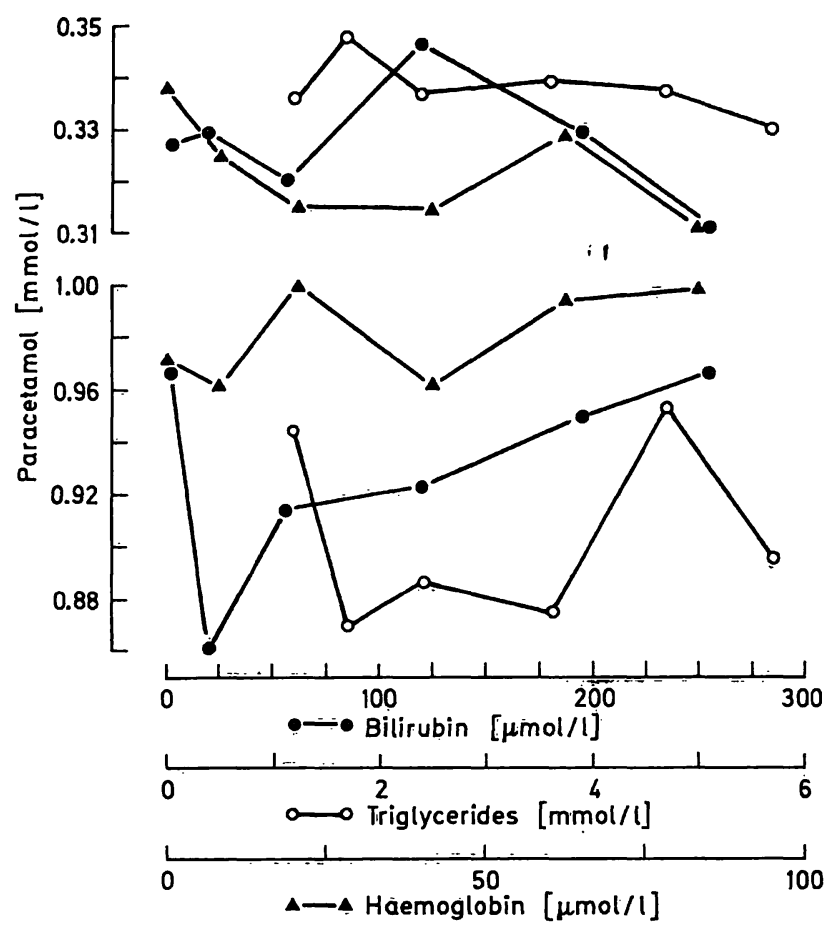

Fig. 4. Effect of haemolysis, icterus and lipaemia on the recovery of paracetamol in the Du Pont $a c a^{\circledR}$ method at two paracetamol concentrations.

\section{Renal patient sera}

Serum from patients with renal failure may be expected to contain raised levels of endogeneous phenolic compounds which might be expected to interfere in the assay.

A total of twenty serum samples from patients with chronic renal failure (creatinine $196-1510 \mu \mathrm{mol} / \mathrm{l}$ ) were tested in a recovery experiment with the addition of paracetamol to 0.5 $\mathrm{mmol} / \mathrm{l}$. Deionised water replaced the paracetamol in the controls.

The recovery of paracetamol was within the range 95 to $111 \%$ with a mean of $102 \%$ for the twenty samples.

\section{Discussion}

Methods for the measurement of paracetamol should be rapid and specific since clinical experience in the management of patients who have taken an overdose of paracetamol suggests that successful treatment depends on quantitation of the parent drug between four and ten hours after drug ingestion (10).

The homogeneous enzyme immunoassay for paracetamol as configured for the $a c a^{\circledR}$ series of discrete analysers described offers a rapid, specific and precise method for the parent drug. 
Initially the precision of the assay, especially at paracetamol concentrations close to the top calibrator, was unacceptable. This was reflected in the variability of the value of the top calibrator observed in the weekly calibration checks and probably also accounted for the spread of points in the method comparison. The second lot of test packs, which were prepared to overcome this initial imprecision, by increasing the rate of absorbance change differential between the 1.0 and $1.3 \mathrm{mmol} / 1$ paracetamol calibrators, improved the precision dramatically (tab. 1). As was expected, the variability in the top calibrator value observed in the weekly calibration checks also became less.

Apart from these problems the assay showed good analytical recovery and was unaffected by a range of metabolites. This latter group are perhaps the most important interferents to consider as in several methods they lead to the overestimation of the drug concentration by hydrolysis of the metabolites to parent drug $(3,10)$. No significant interference was found with compounds administered as antidotes to paracetamol poisoning nor with any of twenty five commonly prescribed drugs. There was no significant interference from the physiological interferents hae-

\section{References}

1. Prescott, L. F., Newton, R. W., Swainson, C. P., Wright, N., Forrest, A. R. W. \& Matthew, H. (1974) Lancet I, $588-592$.

2. Prescott, L. F. (1978) Health Bulletin 36, 204-212.

3. Wiener, K. (1978) Ann. Clin. Biochem. 15, 187-196.

4. Huggett, A., Andrews, P. \& Flanagan, R. J. (1981) J. Chromatogr. 209, 67-76.

5. Horvitz, R. A. \& Jatlow, P. I. (1977) Clin. Chem. 23, 1596-1598.

6. Price, C. P., Hammond, P. M. \& Scawen, M. D. (1983) Clin. Chem. 29, $358-361$.

7. Kabakoff, D. S. \& Grèenwood, H. M. (1981) In: Recent Advances in Clinical Biochemistry 2 (Alberti, K. G. M. M. \& Price, C. P., eds.) Churchill Livingstone, Edinburgh, pp. $1-30$. moglobin, lipaemia or bilirubin. In the case of the high paracetamol pool spiked with these compounds the variability can be attributed to the poor precision of the method at this concentration seen with the first pack lot provided. Samples from patients with chronic renal failure (creatinine 196-1510 $\mu \mathrm{mol} / \mathrm{l}$ ) were also without effect. The homogeneous immunoassay described offers an alternative rapid method for the determination of paracetamol. In common with the enzymatic assay (9) it is specific for the parent compound, a specificity which has been, to date, offered by the chromatographic procedures. The combination of the described assay with a fully automated system such as the Du Pont $a c a^{\circledR}$ series of analysers, where strict control of all aspects of the analytical system, e.g. temperature, pipetting, absorbance measurement and reagent manufacture are possible, yields a highly stable and precise assay for paracetamol.

\section{Acknowledgement}

The authors are grateful to E.I. Du Pont de Nemours, Wilmington, Delaware, U.S.A. for the loan of equipment and provision of the reagents used in this work, and to Mrs. $E$. Moss for typing the manuscript of this paper.
8. Dito, W. R. (1981) In: Interpretations in Therapeutic Drug Monitoring (Baer, D. M. \& Dito, W. R., eds.) American Association of Clinical Pathologists, Chicago, pp. $235-252$.

9. Hammond, P. M., Scawen, M. D., Atkinson, T., Campbell, R. S. \& Price, C. P. (1984) Anal. Biochem. 143, 152-157.

10. Stewart, M. J., Adriaenssens, P. I., Jarvie, D. R. \& Prescott, L. F. (1979) Ann. Clin. Biochem. 16, 89-95.

11. Cornbleet, P. J. \& Gochman, N. (1979) Clin. Chem. 25, $432-438$.

\section{R. S. Campbell}

Department of Clinical Biochemistry,

Addenbrooke's Hospital,

Hills Road,

Cambridge CB2 2QR

U. K. 